\title{
Correction to: Enhancing task-demands disrupts learning but enhances transfer gains in short-term task-switching training
}

\author{
Katrina Sabah ${ }^{1} \cdot$ Thomas Dolk $^{1} \cdot$ Nachshon Meiran $^{2} \cdot$ Gesine Dreisbach $^{1}$
}

Published online: 21 July 2021

(c) The Author(s) 2021

\section{Correction to: Psychological Research (2021) 85:1473-1487 https://doi.org/10.1007/s00426-020-01335-y}

The article "Enhancing task-demands disrupts learning but enhances transfer gains in short-term task-switching training", written by Katrina Sabah, Thomas Dolk, Nachshon Meiran and Gesine Dreisbach, was originally published Online First without Open Access. After publication in volume 85 , issue 4 , page 1473-1487 the author decided to opt for Open Choice and to make the article an Open Access publication. Therefore, the copyright of the article has been changed to (C) The Author(s) 2020 and the article is forthwith distributed under the terms of the Creative Commons Attribution 4.0 International License, which permits use, sharing, adaptation, distribution and reproduction in any medium or format, as long as you give appropriate credit to the original author(s) and the source, provide a link to the Creative Commons licence, and indicate if changes were made. The images or other third party material in this article are included in the article's Creative Commons licence, unless indicated otherwise in a credit line to the material. If material is not included in the article's Creative Commons licence and your intended use is not permitted by statutory regulation or exceeds the permitted use, you will need to obtain permission directly from the copyright holder. To view a copy of this licence, visit http://creativecommons. org/licenses/by/4.0.

Open access funding enabled and organized by Projekt DEAL.

Original article has been corrected.

Open Access This article is licensed under a Creative Commons Attribution 4.0 International License, which permits use, sharing, adaptation, distribution and reproduction in any medium or format, as long as you give appropriate credit to the original author(s) and the source, provide a link to the Creative Commons licence, and indicate if changes were made. The images or other third party material in this article are included in the article's Creative Commons licence, unless indicated otherwise in a credit line to the material. If material is not included in the article's Creative Commons licence and your intended use is not permitted by statutory regulation or exceeds the permitted use, you will need to obtain permission directly from the copyright holder. To view a copy of this licence, visit http://creativecommons.org/licenses/by/4.0/.

Publisher's Note Springer Nature remains neutral with regard to jurisdictional claims in published maps and institutional affiliations.

The original article can be found online at https://doi.org/10.1007/ s00426-020-01335-y.

Katrina Sabah

Katrina.Sabah@psychologie.uni-regensburg.de

1 Department for Experimental Psychology, Regensburg

University, Universitätstraße 31, 93053 Regensburg,

Germany

2 Ben Gurion Univsersity of the Negev, Beersheba, Israel 